\title{
GROUNDWATER ANALYSIS IN THE VICINITY OF NAG RIVER
}

\author{
Khalid Ansari ${ }^{1}$, S.R. Khandeshwar ${ }^{2}$ \\ ${ }^{1}$ Asstt. Professor Department of Civil Engineering, YCCE, Nagpur \\ ${ }^{2}$ Professor Department of Civil Engineering, YCCE, Nagpur
}

\begin{abstract}
The objective of this research studies is to analyse the water and waste water characteristics of Nag river and groundwater quality in the vicinity of the river. Nag River, which serves as the tributary of the Kanhan River originates in the hills to the west of Nagpur and flows in a serpentine course past Nagpur City, joining the main river at Saongi in the east of the District. Today most of the Nagpur sewage is let into Nag River tributaries without any sufficient treatments, which includes wastes, hazardous in nature of this river which crosses the city which has population of about 50 lakh, which makes the river extremely polluted. The River which titled the city is now struggling for its own existence. For the analysis purpose of the river, by whose name lots of people swear as their mother, has been divided into five areas based on the occupancy. The values from the studies were found to be problematic in the vicinity and nearby area. In the present study, groundwater samples of monsoon, winter and summer season of the selected five different zones of the city were taken for the investigation and analyzed for various parameters with re gard to drinking water standards and assessed for their suitability for human consumption. The results of ground water direct us to the fact that the pollution in Nag river has its effect on the ground water as well as the Water Quality Index (WQI) which reflect a composite influence of contributing factors on the quality of water for any water system
\end{abstract}

Keywords: Water \& Waste Water Quality, Nag River and Nagpur, groundwater, physico-chemical characteristics, pollution, water quality index

\section{INTRODUCTION}

India is bountified with vast and varying topography including lots of water bodies. Lakes and rivers serve as source of water and have been doing so from decades and centuries. These rivers not only serve for domestic and industrial benefits but also come in handy when required for strategic plans. It is the time to realize that these vital sources of water which should be conserved and maintained for their long life. History has it, that renowned civilizations of the World have been flourished on the banks of the rivers which further rose as great and powerful empires. Through the ages, Rivers have witnessed lots of development along their sides. The Nag River, of Nagpur city is located at the exact centre of the Indian Peninsula; its snake like nature of flow might have given it the name supposedly, which in turn has nomenclated the city of Nagpur. Almost all the premises, may it be residential or industrial directly discharge the wastes into the river course without required treatments which tends to hamper the condition of the river. The water quality deteriorates mainly due to human acts such as disposal of dead bodies, discharges of industrial and sewage wastes and agricultural runoff which interferes the natural state of the river and thus contributes as major cause of ecological damage and pose serious health hazards (Meitei etal. 2004).

To improve the water and waste water quality it becomes pretty essential from Government point of view to take required actions accordingly. The energetic involvement of the residents at large can assure restoring of status of this river. Various factors like temperature, turbidity, nutrients, hardness, alkalinity and dissolved oxygen play an important role for the growth of plants and animals in water body, on the other hand biological oxygen demand indicate the pollution level of the water body (Kamal et al., 2007). The present scenario of Nag River is that it's heavily contaminated by let go approach \& wrongdoings by the community which leads to classic example of the mismanagement of the rivers.

\section{NEED OF THE STUDY}

The observations suggest that contamination is mostly in the surface part of the river. Most of the diseases that have aroused are proven to be water borne according to the stats given by medical college. So, for the effective investigation of this issue to ensure a brighter, generative action-process and good management strategies to evaluate the water pollution loads from varying sources, easy upkeep after the cleaning up should be at hands and the project results should be modest i.e. the end findings should be in favors for citizens and visitors of Nagpur. So, the project should be significant enough to spread awareness amongst the individuals of the society and this should contribute to cultural, regional, global or biological manner. The level of contamination of the total loads of pollution discharged in the river was justified on the basis of different stations and seasonal changes. The adversely affected Nag and kanhan river corresponds to the drinking water problem for villages situated alongside the bank of river Waingangā which is at a distance of 30-km from Gosikhurd dam to Korambi near Bhandara town. The damage caused is so gravely serious that the water has lost its portability to such extent that even cattles do not resort to drink it, fish are getting killed and the polluted water is all set to cause serious threat to lives of 
villagers. Thus it becomes quite necessary to realize the need to treat the river and this has been understood by the public. Accordingly, the local authorities have opted to clean the river for the very same reason .The cleaning operation was executed couple of years past and hence the corresponding levels of pollution should be kept in vision.

\section{SAMPLING LOCATIONS+}

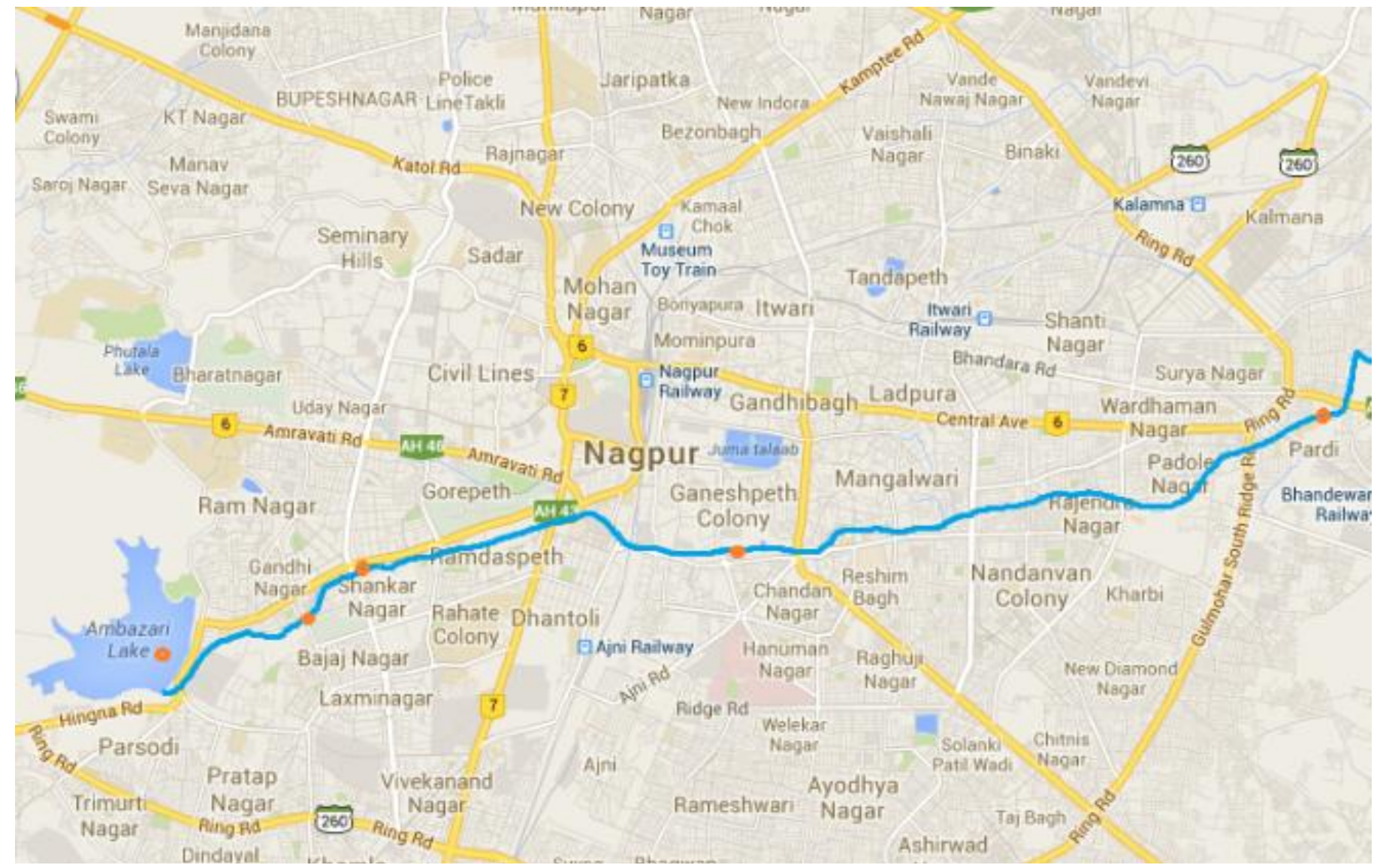

\begin{tabular}{|l|l|l|}
\hline $\begin{array}{l}\text { SAMPLING } \\
\text { LOCATION OF } \\
\text { GROUND } \\
\text { WATER }\end{array}$ & TYPE OF & DISTANCE \\
BETWECTION & $\begin{array}{l}\text { NAG RIVER } \\
\text { AND } \\
\text { GROUND } \\
\text { WATEWR } \\
\text { SOURCE(mt) }\end{array}$ \\
\hline $\begin{array}{l}\text { 1. SUBHASH } \\
\text { NGR.AMBAZARI (S1) }\end{array}$ & WELL & 96 \\
\hline $\begin{array}{l}\text { 2. DAGA LAYOUT, } \\
\text { VNIT(S2) }\end{array}$ & HANDPUMP & 82 \\
\hline $\begin{array}{l}\text { 3.297, SHANKAR } \\
\text { NAGAR(S3) }\end{array}$ & WELL & 95 \\
\hline $\begin{array}{l}\text { 4.PANCHSHEEL } \\
\text { SQUARE(S4) }\end{array}$ & WELL & 91 \\
\hline 5. PARDI(S5) & WELL & 83 \\
\hline
\end{tabular}

\section{METHODOLOGY}

To flash out the extent of pollution of the Nag river and ground water in its vicinity, the methodology is adopted for this project by studying the various affecting parameters. For this, five sampling stations were observed which are well identified areas of Nagpur city along the nag river and the readings were taken accordingly in Monsoon, summer and winter seasons. The parameters like $\mathrm{pH}$, alkalinity, hardness, acidity, chlorides, MPN, BOD, and COD were found out referring standard procedures from INDIAN STANDARDS FOR DRINKING WATER SPECIFICATION ( BIS 10500 : 1991 ) \&(BIS: 22961982).

\section{RESULTS AND DISCUSSION}

The various parameters like BOD and COD were found out and the results showed that it is increasing from station to station. From the various findings, it can be assessed that the BOD and COD values of nag river samples were found to be on the rise from monsoon to winter. The case was similar with the samples brought from the wells in the vicinity of the river indicating that the river water was re-aerated during the monsoon season. This results in replenishment of ground water sources as well. The acidity, alkalinity and chloride content of water samples was comparatively found to be added up in monsoon season than in winter indicating the presence of acid rains in Nagpur region. The bacterial count of samples was quite less in monsoon season in comparison with winter season. Hardness of the river sample was mainly found to be based on the very characteristics and properties of the corresponding type of area it passed by through namely urbanized, commercial or industrialized. 
Looking at the possession of the land by the government, by the sides of the river channel, miniature waste water treatment plants can be installed at areas like VNIT, Shankar nagar Garden, Gangabai Ghat, Wathoda and finally the existing waste water treatment plant at Bhandewadi. The miniature treatment plant should be geared up with efficient mechanism and machinery like Rotating bed contractors, sludge dryers or even anaerobic sludge digesters. The uninterrupted curing of the water will boost up the self purification competence of the river, rebirth of the aquatic life, fighting and outfoxing the odor worries, mosquito problem and upgrades in the quality of water in sub-surface sources like wells and bore wells, reducing the swelling of water-borne diseases amongst the people who are opting out the sub-surface sources as the source of drinking water.

WQI consequences showed that the results were within the permissible range with just Pardi falling out of the expectations. This enlightens the fact that these fall outs are due to the industrial nature of the zone.
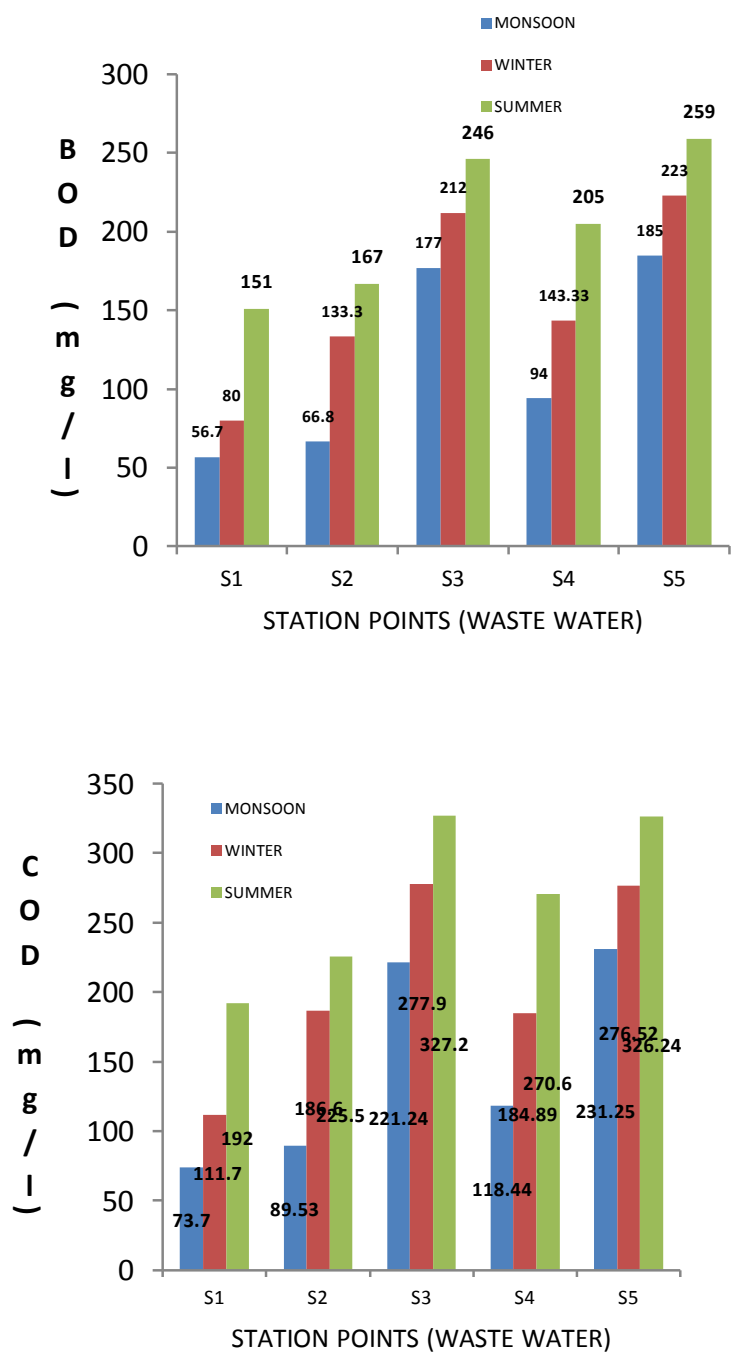
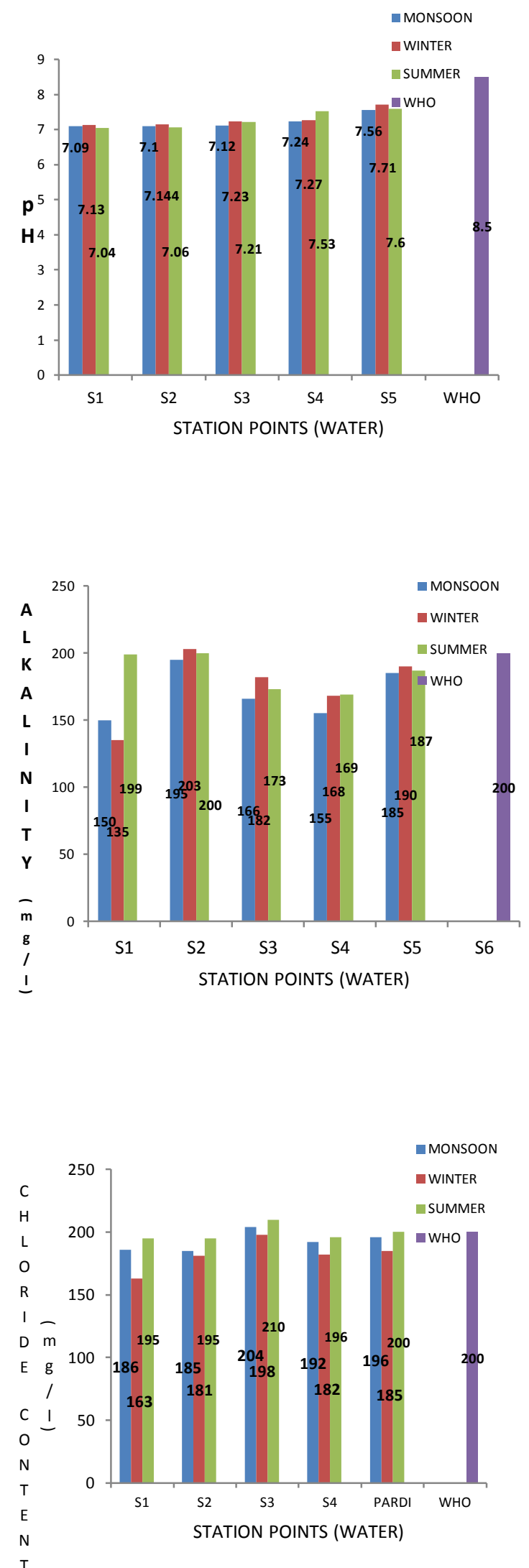

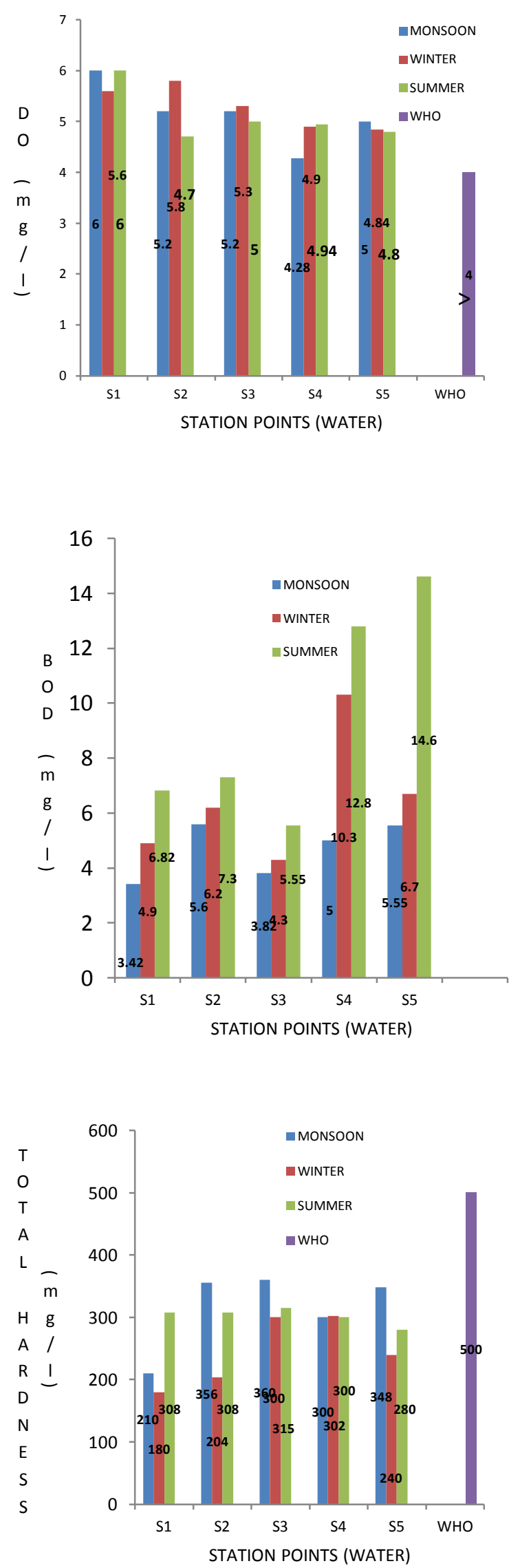

\section{WATER QUALITY INDEX:}

A drinking water quality index is a means to summarize large amounts of water quality data into simple terms for reporting to management and the public in a consistent manner. Water quality index(WQI) is a single value indicator to the water quality. It integrates the data pool generated after collecting due weights to the different parameters.

\subsection{Calculation}

Water quality index (WQI) has been calculated by using the standards of drinking water quality recommended by the World Health Organization (WHO) and the Bureau of Indian Standards (BIS). The Weighted Arithmetic Index Method has been used for the calculation of WQI of water samples using the following expression:

$\mathrm{WQI}=\sum \mathrm{QiWi} / \sum \mathrm{Wi}$

Determination of WQI by Weighted Arithmetic Index Method

- $\quad \mathrm{WQI}=\sum \mathrm{QiWi} / \sum \mathrm{Wi}$

- Where Qi - Quality rating corresponding to the water quality parameter

Qi is a number reflecting the relative value of ith parameter in the polluted water with respect to its Standard permissible value.

- Wi - Relative weight or unit weight of ith parameter, $\mathrm{Wi}=1 / \mathrm{Si}$

- $\quad \mathrm{Si}-\mathrm{Std}$ permissible value

- $\mathrm{Qi}=100[(\mathrm{Vn}-\mathrm{Vi}) /(\mathrm{Vs}-\mathrm{Vi})]$

- $\quad \mathrm{Vn}-$ actual or test value of the parameter at a given sampling station

- $\quad \mathrm{Vi}$ - ideal value of the parameter $\mathrm{Vi}=7.0$ (for $\mathrm{pH}$ ), $\mathrm{Vi}=14.6$ (for $\mathrm{DO}$ ), $\mathrm{Vi}=0$ (for all other parameters)

- $\quad$ Vs - recommended WHO/BIS std of parameter Thus, the overall WQI has been calculated by aggregating the quality rating with the unit weight linearly.

- Water Quality Index Ranges

\begin{tabular}{|l|l|}
\hline WQI VALUES & WATER QUALITY \\
\hline Less than 50 & Excellent \\
\hline $50-100$ & Good water \\
\hline $100-200$ & Poor water \\
\hline $200-300$ & Very poor water \\
\hline Above 300 & Water unsuitable for drinking \\
\hline
\end{tabular}




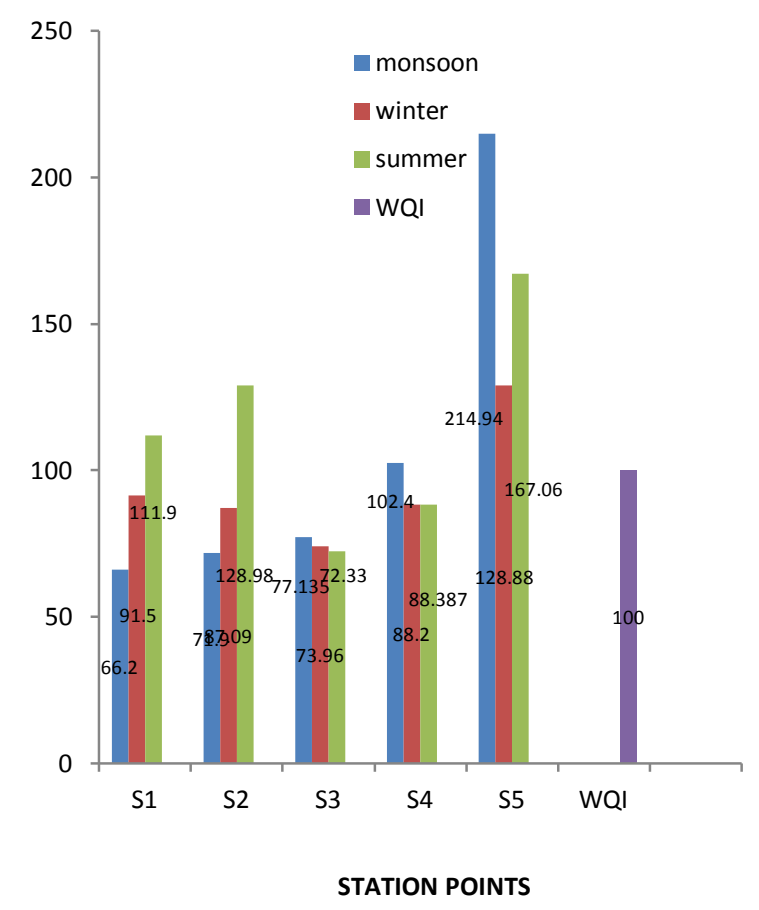

\section{CONCLUSION}

The domestic and industrial waste water is discharged directly in the Nag River, because of this; its water has been severely polluted. . The river looks like a 'sewerage drain' than a river. The observed values of most of the important water quality parameters also indicate that the river water is highly polluted. This is an alarming situation as the water is used for irrigating land on both the banks of the river. The flows also contaminate ground water which is primary sources of domestic water supply in the nearby area. The river further carries the polluted water to Gosikhurd dam which supply water for irrigation, domestic consumption and industrial uses. A visual observation indicates pollution in water of Gosikhurd dam also. This is an disturbing situation and need to be tackled on priority. Nagpur Municipal Corporation has proposed some measures for purification of the river. However, they have to act fast so that the situation does not go out of control.

The computed water quality index values indicate the suitability of water for drinking purposes. These values are in the permissible range for almost all the regions except in Pardi, indicating the industrial nature of the region. The industrial discharge in the Nag River herein is so toxic that it does not even spare the ground water.

\section{REFERENCES}

[1]. Faith Ngwenya, (2006). "Water Quality Trends in the Eerste River", Western Cape, 1990-2005. A mini thesis submitted in partial fulfillment of the requirements for the degree of Magister Scientiae, Integrated Water Resources Management in the Faculty of Natural Science, University of Western Cape .pp. 41.
[2]. GIS based qualitative analysis of urban river stream: a case study of nag river urban water shed dist. Nagpur Maharashtra, India PinakRanade. Y.B. Katapatal

[3]. Metcalf and eddy inc: "wastewater engineering, treatment and reuse

[4]. Kamal, D., Khan, A.N., Rahaman, M.A. and Ahamed, F. (2007). "Study on the physic chemical properties of water of Mouri River", Khulna, Bangladesh. Pakistan Journal of Biological Sciences 10 (5): 710-717.

[5] Garrels, R.M., Mackenzie, F.T. and Hunt, C., (1975). "Chemical Cycle and the Global Environment", William Kaufman, New York, p. 260.

[6]. Environmental pollution control engineering-C.S. Rao [7]. APHA. 1992. "Standard methods for the examination of water and waste water. $18^{\text {th }}$ Edition", Washington, D.C.

[8]. Usharani, K., Umarani, K., Ayyasamy, P.M., Shanthi, K. and Lakshmanaperumalsamy, P. (2010). "PhysicoChemical and Bacteriological Characteristics of Noyyal River and Ground Water Quality of Perur", India. J. Appl. Sci. Environ. Manage. Vol.14(2) 29-35.

[9]. Sahu, V.P., (1993). "Pollution study of river Ganga at Kanpur and Farukhabad using water quality indices", M.E.Dissertation (unpublished), Environmental Engineering Division Department of Civil Engineering, University of Roorkee.

[10]. Chang, H. (2008). "Spatial analysis of water quality trends in the Han River Basin, South Korea". Water Research, 42(13): 3285-3304.

[11]. Mamais, d., Jenkins, D. and Prrr, P. (1993). "A rapid physicalchemical method for the determination of readily biodegradable soluble COD in municipal wastewater". Water Research, 27(1): 195-197.

[12]. Anibal f. Condor_golec1, Pablo Gonzalez Perez2 ChinmayLokare effective microorganisms: myth or reality?' rev. Peru Biol14(2): 315-319 (diciembre, 2007).

[13]. Mishra, A., Mukherjee, A. and Tripathi, B.D. (2009)." Seasonal and Temporal Variation in PhysicoChemical and Bacteriological Characteristics of River Ganga in Varansi. Int. J. Environ". Res., 3(3): 395-402.

[14]. www.mapleorgtech.com

[15]. Abida, B. and Harikrishna (2008). "Study on the Quality of Water in Some Streams of Cauvery River", EJournal of Chemistry, 5, (2): 377-384.

[16]. Singh, M.R., Gupta, Asha. andBeeteswari, KH. (2010). "Physico-chemical properties of Water samples from manipur river system", India.J.Appl.Sci.Environ.Manage. Vol. 14(4) 